\title{
Impact of management measures on the European ground squirrel population development
}

\author{
Peter Petluš $^{1 *}$, Viera Petlušová ${ }^{1}$, Ivan Baláž ${ }^{1}$, Michal Ševčík ${ }^{1}$, Andrea Lešová $^{2,3}{ }^{3}$ Ervín Hapl $^{4}$ \\ ${ }^{1}$ Department of Ecology and Environmental Sciences, Faculty of Natural Sciences, Constantine the Philosopher \\ University, Nitra, Tr. A. Hlinku 1, 94974 Nitra, Slovakia \\ ${ }^{2}$ State Nature Conservancy of the Slovak Republic, Banská Bystrica, Tajovského 28B, \\ 97401 Banská Bystrica, Slovakia \\ ${ }^{3}$ Technical University in Zvolen, Faculty of Forestry, Department of Applied Zoology \\ and Wildlife Management, T.G. Masaryka 20, Zvolen, 96001 Slovakia \\ ${ }^{4}$ Raptor Protection of Slovakia, Trhová 54, 84101 Bratislava, Slovakia
}

\begin{abstract}
Petluš, P., Petlušová, V., Baláž, I., ŠEvČíK, M., LeŠovÁ, A., HaPL, E., 2021. Impact of management measures on the European ground squirrel population development. Folia Oecologica, 48 (2): 169-179.

In the past, the European ground squirrel represented a common part of Slovakian fauna. During the 20th century, there was a substantial decrease in its number, mainly due to the intensification of agriculture. Currently, several programs focused on the recovery and preservation of ground squirrel colonies have been implemented. The aim in supporting the population of the European ground squirrel is to increase the number of birds of prey and to ensure a food base for them. In this paper, we focus on evaluating the success rate of European ground squirrel (Spermophilus citellus) management measures. The research was realized at two localities in the Protected Bird Area Slovenský kras (Hrhov and Gemerská Hôrka) in the years 2015-2018. Activities were focused on the management of grassland and supplemental feeding during the breeding period. As a result of the management measures and the supplemental feeding, we managed to maintain a positive trend in the populations' development, as there was an increase observed in all the monitored seasons.
\end{abstract}

\section{Keywords}

bird of prey, feeding landscape management, population density, restitution, Spermophilus citellus

\section{Introduction}

The European ground squirrel, Spermophilus citellus, represented a common part of Slovakian fauna in the past. GRULICH (1960) noted a very high density of the local ground squirrel population. The core of the ground squirrel's distribution was on grazed and mowed sites on traditional agrarian land. By moving away from traditional cultivation, intensifying agricultural land, increasing the use of chemical practices in agriculture, and ploughing meadows and pasturelands (and their overgrowth), the original strongholds of the ground squirrel population perished. AMBros and HAPL (2008) highlighted the changes in traditional agricultural techniques over a short period of time to be the main reason for the species' significant decrease, causing their populations to perish. Presently, the ground squirrel is widespread only in Central and South-eastern Europe. It came to Central Europe from the center of its

\footnotetext{
*Corresponding author: e-mail: ppetlus@ukf.sk 
distribution on the Balkan Peninsula concurrently with the human impact of vast deforestation of the land (SPITZENBERGER and BAUER, 2001). During the beginning and middle of the last century, the population was widespread in Hungary, Austria, Slovakia, and the Czech Republic. In that time, it reached its optimum in the area. From an anthropic perspective of nature, the ground squirrel was serious vermin for agricultural crops. This fact also led to the application of the scientific method to kill off ground squirrel populations (GRULICH, 1955, 1980). From 1996 to 2008 , colonies of the European ground squirrel were confirmed in 120 Slovak localities (AmBros, 2008a). By the end of the last century, a drastic decline and decrease in the population density related to changes of land use was observed (Del Hoyo et al., 1995; BeliK et al., 2002; Chavko et al., 2007). Overview the survey results shows that the population distribution area in Slovakia has been losing its continuity since 1950 by breaking into many segments. At the present time, the areas with the highest population density of European ground squirrel are the highlands of Cerová vrchovina, the karst of Slovenský kras, and the basin of Hornádska kotlina. Pasturelands and meadows that use traditional or similar methods of cultivation have been preserved in these areas. The decrease and gradual disappearance of the ground squirrel has had an impact on the diet base of raptors. Ground squirrels (Spermophillus sp.) represent a significant dietary element of the Eastern imperial eagle Aquila heliaca (Del Hoyo et al., 1995; HaraszTHY et al., 1996; BELIK et al., 2002; CHAVKo et al., 2007; KARYAKIN et al., 2011) and the saker falcon Falco cherrug (Овuch and Chavko, 1997; Снavko, 2010; Chavko and DeuTSCHOvé, 2012), but presently the ground squirrel representation in the diets of both species in Central Europe is significantly lower (HoRváTH et al., 2010, 2018; СНАVко et al., 2014). The European ground squirrel is an important part of the food chain of raptors (RUŽIĆ, 1978). The presence of the ground squirrel in any locality is a sign of the long-term optimally used cultural landscape under Carpathian conditions. Several earlier studies point to the influence of long-term traditional grazing on the landscape (Hartel et al., 2013; Kosmas et al., 2015; KenYeres et al., 2018; Colantoni et al., 2020).

The European ground squirrel is currently under legislative protection. Pursuant to Act No. 543/2002 Coll. of the National Council of the Slovak Republic on Nature and Landscape Protections, this ground squirrel is an autochthonous protected fauna species for conservation. According to the Red List of Slovak Mammals (ŽIAK and UrbaN, 2001), the ground squirrel is classified as an endangered (EN) taxon. In the proposal of the Red List of Endangered Mammals of the Carpathian Mountains, it is classified under the category of vulnerable taxa (URBAN and UHRIN, 2014).

In an international context, the conservation of the European ground squirrel proceeds from the Council Directive 92/43/EEC on the Conservation of Natural Habitats and of Wild Fauna and Flora. As the current report on the condition of species and biotopes of conservation indicates, the ground squirrel is in bad condition in the Alpine and Pannonian biogeographical region (ČERNECKÝ et al., 2014). The presumed population number in the Slovak Republic is 1,000-1,500 individuals. The short-term and long-term population trends of the European ground squirrel are, moreover, decreasing (AMBRos, 2008a).

The various causes of this population density decrease, the gradual reduction of the localities where the species occurs, and the species passing into uncharacteristic habitat areas (BALÁž and ZALuBiLová, 2005; AmBros, 2008b) have led to a need for implementation of a restitution process and the provision of optimal conditions under various management measures. According to (KLINDA, 2000), restitution is a reversion of organisms to the place of their original occurrence, where they became extinct. The restitution (or repatriation, where species return to their original localities) of the European ground squirrel was elaborated in detail in (AMBROS, 1999; HAPL, 2001; HAPL et al., 2006), which describes repatriation in Eastern Slovakia using the methodology of noose trapping. The authors Ambros et al. (2004), TuHÁRSKA and BALÁž (2006) presented the results of their repatriation of the ground squirrel from some of the original localities in the foothills of Malé Karpaty (Little Carpathians) and the plains of Muránska planina.

At present, the number of localities implementing measures to improve the ground squirrel population is growing. HAPL et al. (2018) stated that, until 2018, a growing population trend was achieved in seven localities, of which three were formed by species restitution.

Knowledge on the current condition and distribution of the European ground squirrel in Slovakia is based mainly on the species surveys implemented within the programmes and projects of the State Nature Conservancy of the Slovak Republic (SNCSR) and the Raptor Protection of Slovakia (RPS).

The objective of this paper is to evaluate the success of the management measures on the European ground squirrel (Spermophilus citellus) in two localities in the Protected Bird Area of Slovenský Kras (Hrhov and Gemerská Hôrka). In order to support the population of birds of prey, especially European ground squirrel specialists such as Aquila heliaca and Falco cherrug.

\section{Materials and methods}

\section{Studied species}

The European ground squirrel is a rodent, originally bound to a steppe environment. This squirrel species came to our latitude simultaneously with the development of agriculture (KoMÁREK, 1950). In the past, it inhabited grassy road margins, baulks, mowed meadows, pasturelands, embankments, and the stands of perennial crops (GRULICH, 1960; RužIĆ, 1978; Huloví, 2001). Today, the majority of ground squirrel colonies in Slovakia are bound to regularly mowed areas with long-low grass covers, i.e., mostly airports, cottage colonies, and sports fields (BALÁž et al., 2008). The ground squirrel is spread throughout all soil types with adequate cohesion for the burrowing of underground tunnels. Stony soils also suit the ground squirrel, 
which settles in arable lands only temporarily (GRULICH, 1960). The essential factor of the ground squirrel's survival in a locality is long-low grass cover (short-grass steppe). In high grass, the ground squirrel loses track of its surroundings and becomes easy prey for potential predators (MATĚJŮ et al., 2010). The European ground squirrel wakes up from its winter sleep during the period from March until the end of April, when the soil temperature at the depth of the nest chamber reaches 6 to $8^{\circ} \mathrm{C}$ (GRULICH, 1960). The mating season begins just after hibernation ends and lasts 20 to 25 days (Ružıć, 1978). There are seasonal changes in both the animal and plant food of the ground squirrel (DANILA, 1989). A typical predator of the ground squirrel in this study's environmental conditions is the steppe polecat (Mustela eversmanii). Avian predators mostly include the eastern imperial eagle (Aquila heliaca) (CHAvко et al., 2007) and saker falcon (Falco cherrug) (Chavko, 2010; Chavko and Deutschoví, 2012; Chavko et al., 2014), which are specialized for eating the European ground squirrel in the conditions of Central Europe. Other natural predators of the ground squirrel include Mustela nivalis, M. erminea, M. putorius, Martes foina and Vulpes vulpes, Falco peregrinus, F. cherrug, Buteo buteo, Accipiter gentilis, A. nisus, Clanga clanga, Milvus migrans, Circus cyaneus, C. aeruginosus and Otis tarda (GRULICH, 1960).

\section{Study area}

The study area comprises two localities in the southern part of the Rožňava region in the geomorphological unit of Slovenský kras (at the borderline of the National park of Slovenský kras - karst).

Gemerská Hôrka is located at the border of the cadastral areas of Gemerská Hôrka and Plešivec in the geomorphological division of the plain of Koniarska planina at the mouth of the valley Zimná dolina at an altitude of 270-300 $\mathrm{m}$ asl. The total surface area of this locality is ca. 4.2 hectares. This locality is currently a grassy site containing a military shooting range, which, in 2015 , was overgrown by the natural seeding of young shrubs with the presence of higher weeds. The floristic composition is conditioned by grazing. Species-undefined medium-rich pastures with a dominance of Festuca rupicola with the presence of species of the class Festuco-Brometea are represented. Hrhov is located in the north-western part of the cadastral area of Hrhov village at the border of the geomorphological division of the hills of Horný vrch and the basin of Turnianska kotlina at an altitude of 240-270 m asl with a surface area of ca. 11.6 hectares. This locality is currently used as a mowed meadow. In 2014, the area was an extensively used meadow with occasional mulching, which produced biomass residue.

\section{Management activities}

The management activities in the observed localities included several activities such as the preparation of localities, the clearing of self-seeded shrubs and weeds and the expansive dispersal of invasive plants. Due to the aggressive dispersion of plants, some parts of the localities were cleared from 2015 to 2017. Mowing of the localities was the main activity (Table 1). There was also the provision of supplemental feed in this area, which was carried out primarily in the early spring after the hibernation of the animals and during the females' gestation period immediately before hibernation. This helped the animals overcome the challenging weather conditions. Sunflower seeds, oats, and apples were used as supplemental feed.

\section{Data analysis}

The spatial distribution of the burrows in each session was described using a two-dimensional bivariate normal kernel density estimation with the bandwidth estimated via a normal reference distribution. The relation between the abundance of Spermophilus citellus and the number of burrows, size of the mowed area, and time was described using a linear regression model on a log scale (SEAMAN et al., 1998).

Table 1. Management activities in the observed localities in the years of 2015-2017

\begin{tabular}{|c|c|c|}
\hline Year & Gemerská Hôrka & Hrhov \\
\hline 2015 & $\begin{array}{l}\text { Two parts of the locality mowed by a brush cutter, } \\
\text { 1. A part with a surface area of } 0.9 \text { ha; mowed twice; } \\
\text { 2. A part with a surface area of } 0.04 \text { ha; mowed } 3 \\
\text { times. }\end{array}$ & $\begin{array}{l}\text { Mowing of the whole locality with a surface area of } \\
6.0 \text { ha; mowing of its adjacent parts ( } 12 \text { ha), } \\
\text { performed by the tenants for the purpose of receiving a } \\
\text { grant; transport of biomass; subsequent mowing using } \\
\text { a brush cutter in the vicinity of the burrows; clearing } \\
\text { the passageways between the localities, burning the } \\
\text { biomass. }\end{array}$ \\
\hline 2016 & $\begin{array}{l}\text { Mowing and clearing of biomass in an area of } 2.0 \text { ha; } \\
\text { subsequent mowing by a brush cutter near the burrows } \\
\text { and clearing of the self-seeded shrubs in an area of } .3 \\
\text { ha along with preparation for mowing. }\end{array}$ & $\begin{array}{l}\text { Mowing and clearing the biomass in an area of } 5.0 \text { ha } \\
\text { and subsequent mowing by a brush cutter near the } \\
\text { burrows; the area was also mowed by the tenants. }\end{array}$ \\
\hline 2017 & $\begin{array}{l}\text { Mowing of an area of } 3.0 \text { ha; clearing the self-seeded } \\
\text { shrubs in the alley connecting the inhabited places } \\
\text { with a surface area of } 0.6 \text { ha. }\end{array}$ & $\begin{array}{l}\text { Mowing of an area of } 6.0 \text { ha for the purpose of } \\
\text { creating the conditions for the colony's development; } \\
\text { the area was also mowed by the tenants. }\end{array}$ \\
\hline
\end{tabular}




\section{Results}

In 2015, the LIFE Energy Project activities were mainly directed onto improving the conditions for the European ground squirrel in two localities in the Protected Bird Area of Slovenský kras. In both localities, supplemental feeding by sunflower seeds, oats, and apples was carried out, and, at the same time, mowing and clearing away of the biomass was implemented to create and/or improve good conditions for the populations' survival.

\section{Management activities and the condition of the popu- lation in Gemerská Hôrka from 2015 to 2018}

The initial situation in the locality in 2015 was critical based on the number of individuals in the spring. Here, there were only 16 individuals and 99 active burrows identified (Fig. 1), with the burrows situated in one central (core) part of locality and three smaller isolated patches located at a distance of up to $300 \mathrm{~m}$ from the central locality with one to two individuals. The first type of locality management was mowing. At the end of the season in 2015, some new active burrows were recorded in the central part of the locality, and 30 individuals in total were observed (four pregnant females were observed).
In 2016, there were 135 active burrows identified and 25 individuals observed at the beginning of the season. The locality was fragmented into two parts $225 \mathrm{~m}$ away from each other, and on one of these fragments, only two individuals were observed. The locality management in 2016 focused on interconnecting the two fragments. Before hibernation, 70 individuals were observed in the locality (eight females gave birth).

In 2017, there were 175 active burrows identified and 40 individuals observed at the beginning of the season. The locality continued being fragmented into two disproportionate parts (37 and 3 individuals). At the end of the season, the number of active burrows had almost doubled (about 300), and 90 individuals were observed.

In 2018, 325 burrows and 80 individuals were identified at the beginning of the season. During the last year of the study, the locality continued being fragmented into two disproportionate parts (with 76 and 5 individuals), whose distance apart was smaller $(150 \mathrm{~m})$. In total, 100 individuals were observed at the end of the season.

Based on the data obtained, the density was estimated from the spatial distribution of burrows for each session in each locality. Figure 2 shows the density and scattering of the burrows in the managed locality.

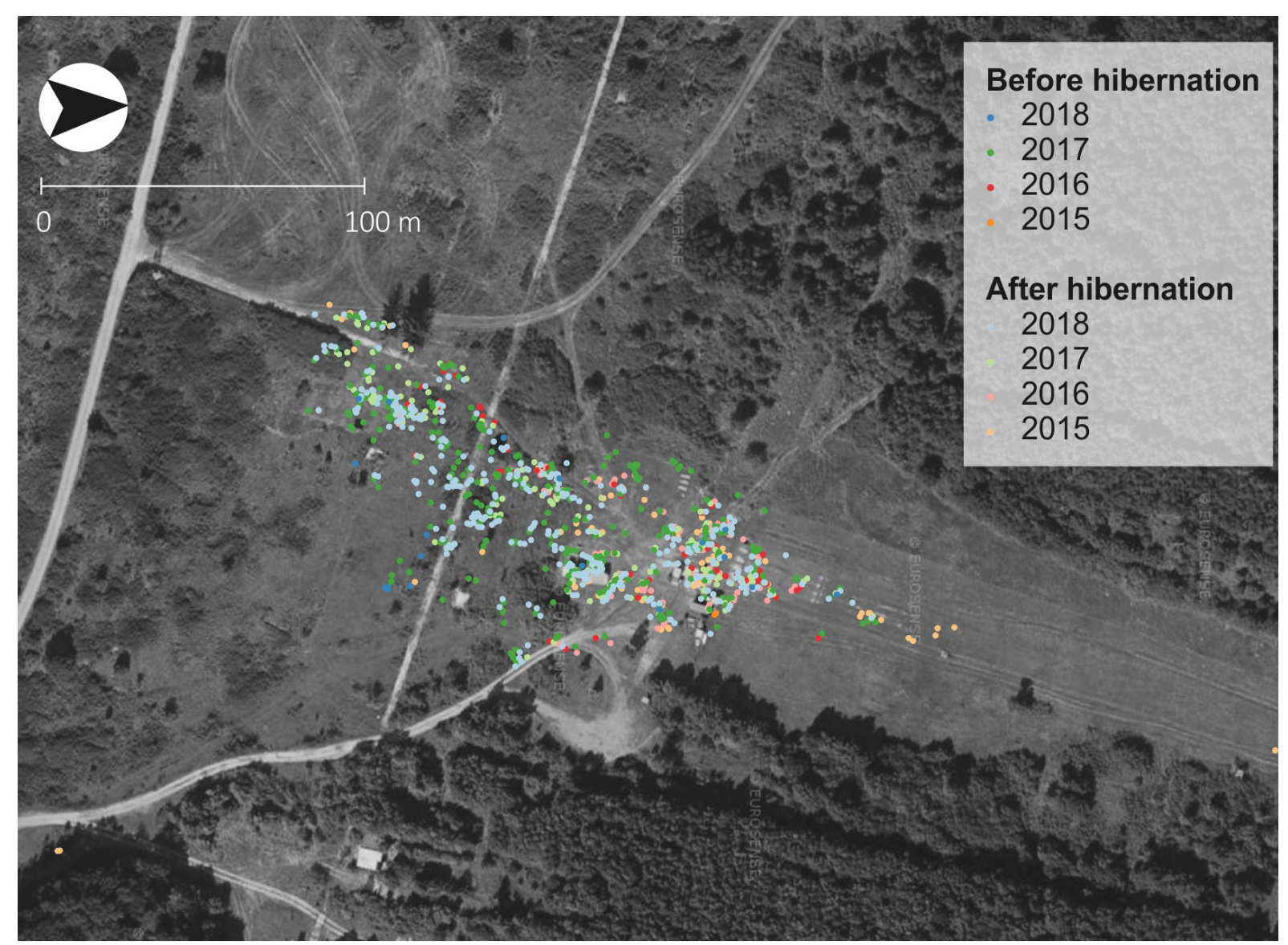

Fig. 1. Distribution of burrows in Gemerská Hôrka before and after hibernation in the years 2015-2018. 


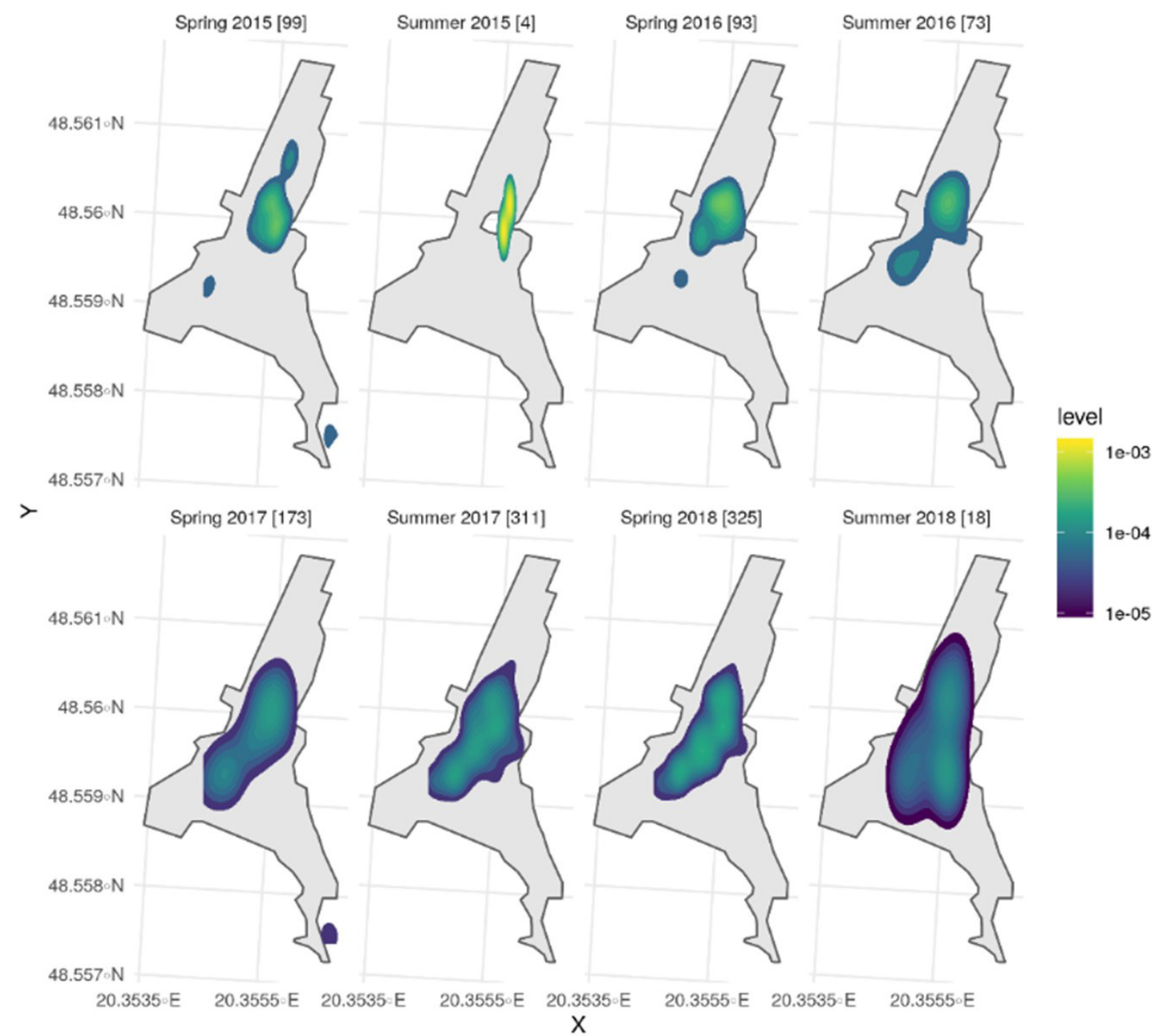

Fig. 2. Kernel density estimation of the spatial distribution of burrows for each session in the locality of Gemerská Hôrka. The numbers in brackets represent the number of burrows. In the case of summer, the number represents the increment of burrows.

\section{Management activities and the condition of the popu- lation in Hrhov from 2015 to 2018}

In Hrhov, the initial situation in 2015 was different regarding the number of individuals and the previous locality management. Since 2014, this locality has been mowed by the tenants within the Rural Development Program.

In 2015, the population was fragmented into two separate parts more than $200 \mathrm{~m}$ apart. At the beginning of the season, 774 burrows were identified, and 75 individuals were observed. At the end of the season, the distance between the fragments was only $100 \mathrm{~m}$, and more than 200 individuals were observed before hibernation.

In 2016, there were 150 individuals observed at the beginning of the season. The distance between the two fragments decreased to $60 \mathrm{~m}$. At the end of the season, the population number increased to 250 individuals. The number of active burrows became higher in this season to 655 , and some changes in distribution were observed. The ground squirrels then began to form compact colonies, as the locality did not provide small islands of suitable refuge but instead area-wide fitting conditions.

At the beginning of the season in 2017, there were 200 individuals observed. The distance decreased to slightly less than $50 \mathrm{~m}$, and the number grew in the eastern fragment. The population conditions were affected by high precipitation, and 300 individuals were observed in autumn just before hibernation.

In the spring of 2018, more than 250 individuals were observed. The distance between both fragments was less than $30 \mathrm{~m}$, and by the end of the season, the fragments were functionally interconnected (Fig. 3). More than 500 individuals were observed at the end of the season.

Based on the data obtained, the density was estimated for the spatial distribution of burrows per session in the locality. Figure 4 shows the density and scattering of burrows in the managed locality.

Through supplemental feeding and the management measures, we managed to maintain the positive trend in the development of the populations in both localities (Fig. 5). 


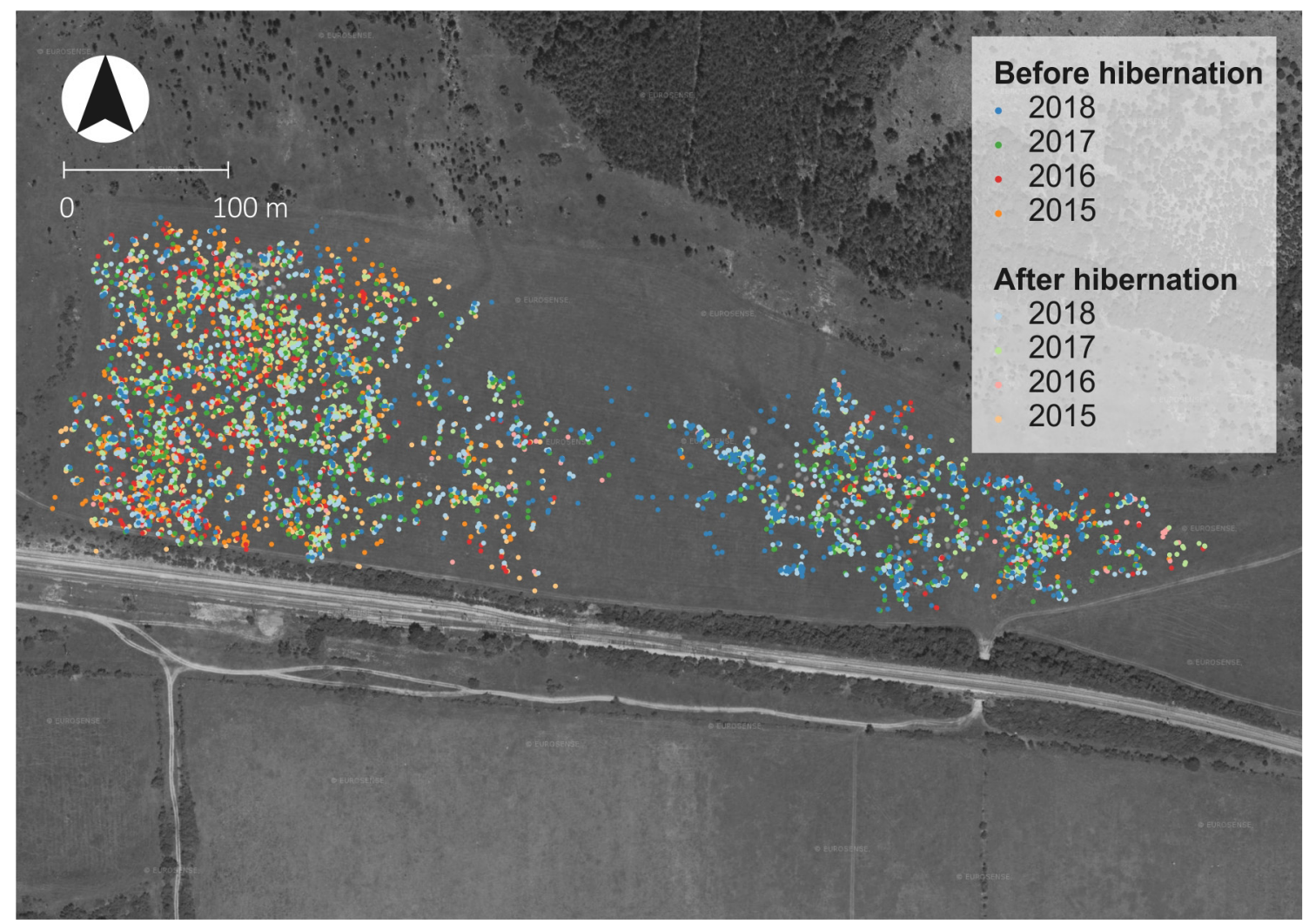

Fig. 3. Distribution of burrows in Hrhov before and after hibernation in the years 2015-2018.

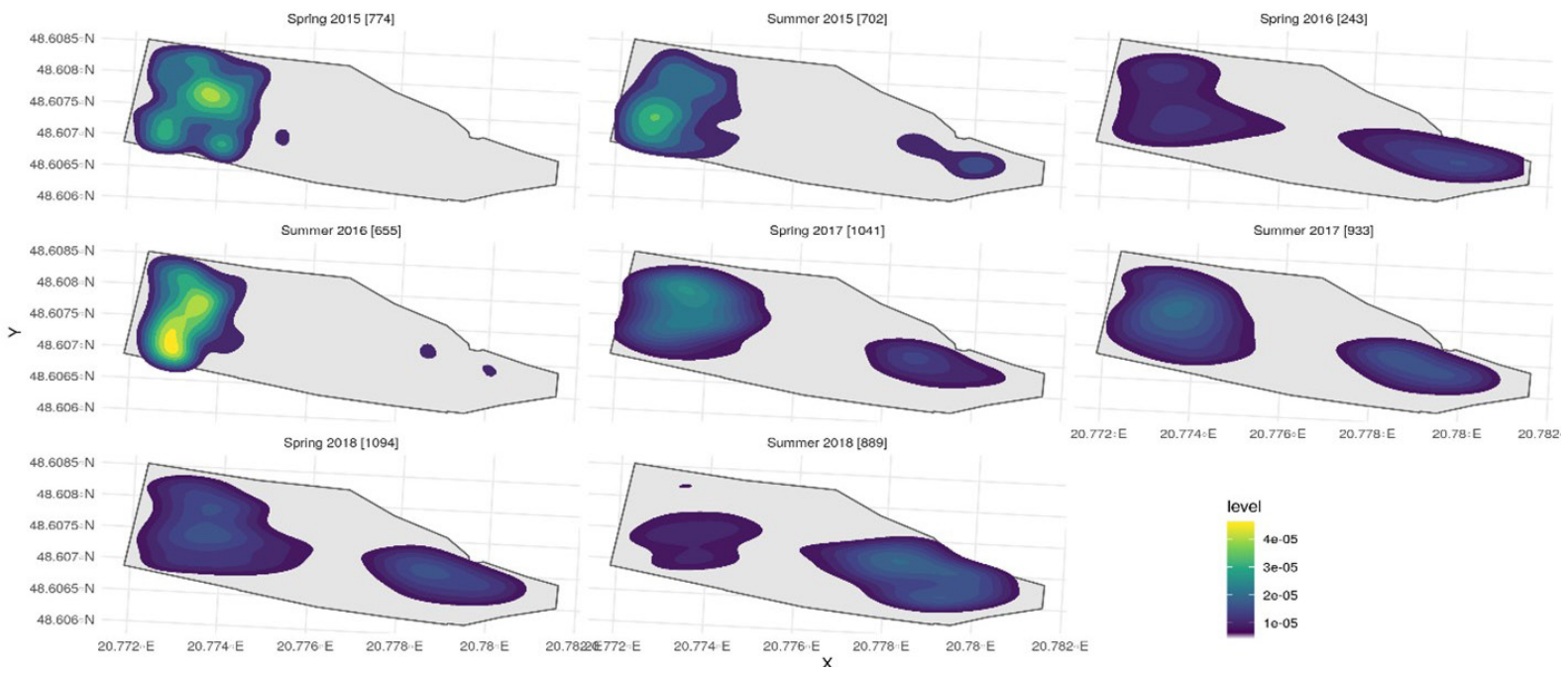

Fig. 4. Kernel density estimation of the spatial distribution of burrows per each session for locality Hrhov (The numbers in brackets represent the number of burrows. In the case of summer, the number represents the increment of burrows).

In all seasons in both localities, the populations increased. The population increased 5 times in Gemerská Hôrka and 3.3 times in Hrhov. The most considerable population growth was recorded in 2016 in Gemerská Hôrka, when the number of individuals increased by $64.3 \%$ ( 45 individuals). In the next year, the number of individuals was also higher (by $55.6 \% ; 50$ individuals). At the same time, in the winter season of 2016/2017, we recorded the highest decrease in the population. As many as 30 individuals did not survive the winter, which was a $42.8 \%$ loss. This fact is also consistent with the lowest recorded growth in the number of individuals during the monitoring of the populations in both localities. In 2018, in Gemerská Hôrka, the population increased by only 20 individuals, which, considering 100 individuals, represents only $25 \%$ increase. The reason for this small increase was the aforementioned 
decrease in the number of individuals during the winter season, which caused a lower number of females to mate during the next season. The average population growth during the mating season for all the seasons in Gemerská Hôrka was $46.6 \%$, and the average drop due to unsuccessful wintering was $23.5 \%$. Hrhov did not show any extreme values in growth or a drop in the population during any of the monitored seasons. The highest growth was recorded in 2015 (by as many as $62.5 \% ; 125$ individuals). In 2017 , we recorded the lowest population growth, which was still growth by $1 / 3$. The population drop due to unsuccessful wintering was no greater than $1 / 4$ of the population in any of the seasons. We consider the population in Hrhov to be more stable, mainly because of the relatively higher number of individuals (about 300).
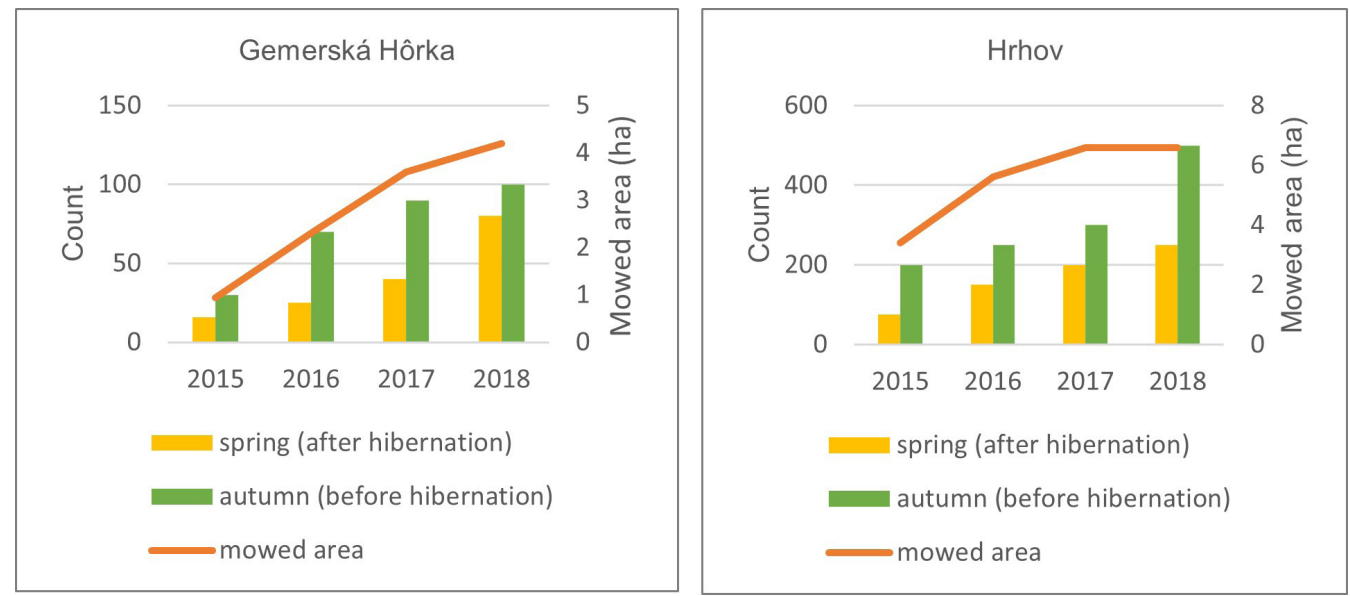

Fig. 5. Development of the number of individuals before and after hibernation and the area of the mowed locality in the years 2015-2018 in Gemerská Hôrka and in Hrhov.
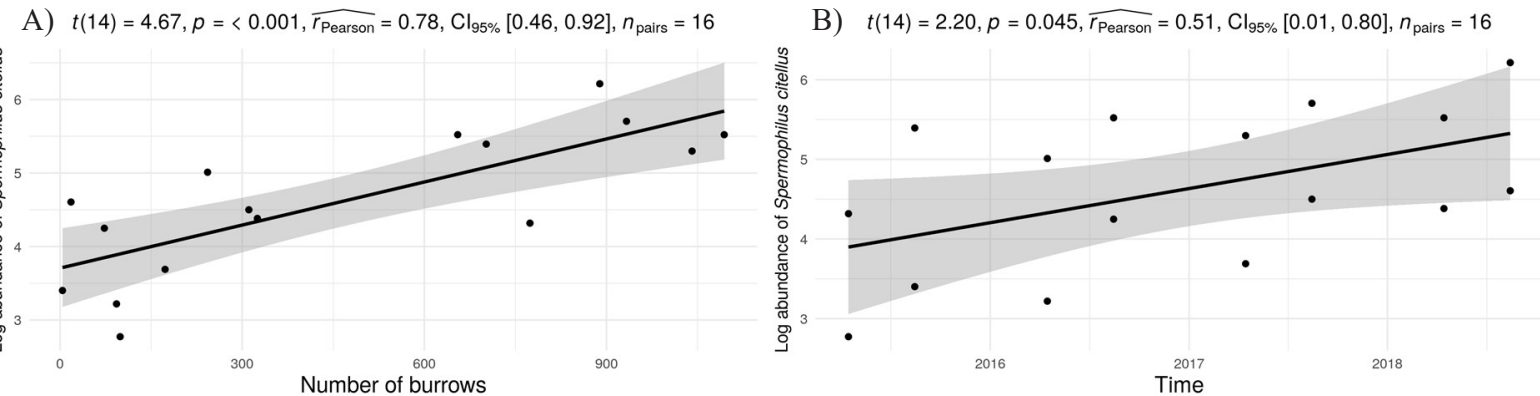

C) $t(14)=7.16, p=\left\langle 0.001, \widehat{r_{\text {Pearson }}}=0.89, \mathrm{Cl}_{95 \%}[0.70,0.96], n_{\text {pairs }}=16\right.$

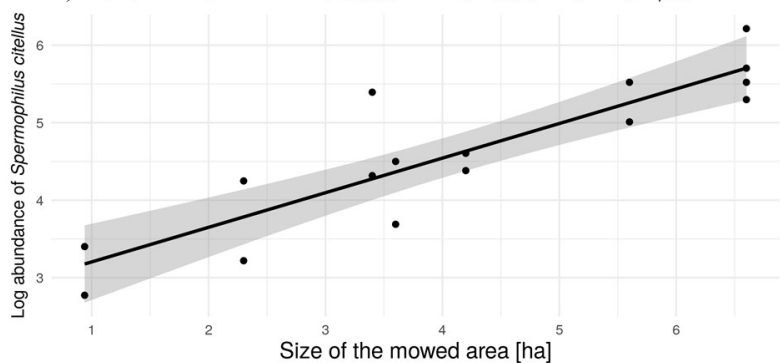

Fig. 6. The relation between the log abundance of Spermophilus citellus and the number of burrows (A), the time, and (B) the size of the mowed area in hectares (C).

The impact of locality management by mowing showed itself to be very significant. Figure 6 shows the relation between the log abundance of Spermophilus citellus and number of the burrows (A), the time, and (B) the size of the mowed area in hectares $(C)$.

Figure 7 illustrates the relationship between the size of the area being managed and the number of individu- als before and after hibernation. The population growth trend is similar in both localities. There is an anomaly here in the form of a lower increase of the number of individuals during the season of 2018 in Gemerská Hôrka, with the highest decrease in the number of individuals caused by flooding of the burrows due to the rapid melting of snow. 

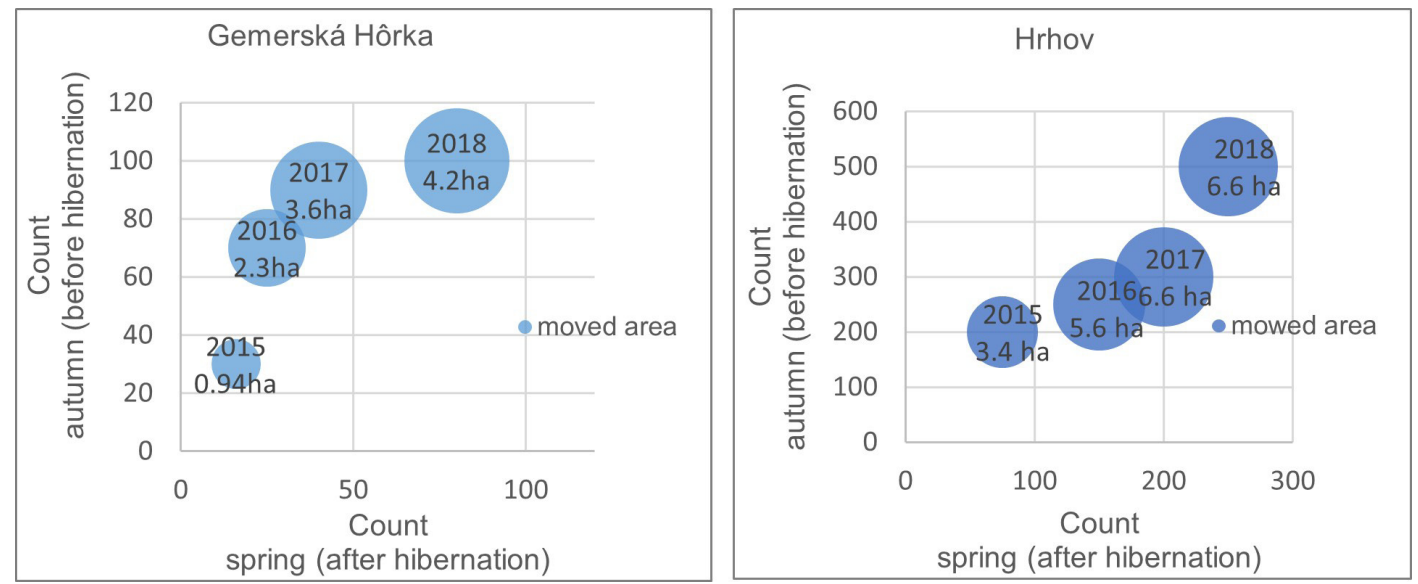

Fig. 7. Relationship between the number of individuals before and after hibernation and the size of the area being managed during the years 2015-2018 in Gemerská Hôrka and Hrhov.

\section{Discussion}

The European ground squirrel is one of the species of mammals whose habitat area has become considerably smaller during the last 50 years (AMBRos and HAPL, 2008), which is reflected in the presence of squirrel-hunting specialist predators. As reported in KARASKA et al. (2015), the abundance of saker falcon in the Protected Bird Area of the Slovak Karst has long been decreasing. No nesting of the species was recorded in 2010-2012. The presence of hunting saker falcon, hawk, and raven during this research may be related to the growing populations of European ground squirrel in the area. To preserve the current distribution area of this steppe species, it is necessary to change its management methods. By applying elements of traditional farming management (grazing and mowing of meadows and pasturelands), we can contribute to the viability of the European ground squirrel in Slovakia. Traditional farming management elements need to be integrated through landscape ecological planning into regional planning documentation or land re-parceling in the individual regions of Slovakia. Another possibility is to implement restitutions (repatriations) to the localities of the ground squirrel's original occurrence (HAPL, 2001; AMBRos et al., 2004).

The management activities in both monitored localities did not avoid the overlap of the managed areas during individual years. This also means that the locality (or at least the most essential part of it) that was mowed in the previous year had to be mowed again. In Gemerská Hôrka, this mowing was carried out repeatedly due to the intensive rejuvenation pruning of blackthorns. In Hrhov, the weather and torrential rain during the years of 2015-2017 made grass grow intensively. However, this grass was not economically interesting for the tenants, so it was also mowed repeatedly. The overlap corresponded to the data taken from the monitoring of ground squirrel burrow distribution. In both cases, we carried out measures at the site using the surface area planned in the project. In both localities, we also carried out measures at the site repeatedly (in some parts as many as four times). In 2018, Gemerská
Hôrka was mowed again due to the intensive rejuvenation pruning of blackthorns. The highest decrease in the population in Gemerská Hôrka was recorded in the winter season of 2016/2017. Likely, this loss was caused by a sudden melting of snow causing flooding of burrows and thus the death of hibernating individuals. In Hrhov, only monitoring was carried out because, after the measures made previously, the condition of the locality was optimal, with no need for further management. In both localities, we performed supplemental feeding continuously. The direct result of the management measures was an increase in the rate of individual survival of the hibernation period (compared to the published average values, e.g. MiLLESI and Hoffmann, 2008). According to Hapl et al. (2018), in the years 2015-2018, there was an increase in the population number by 350 individuals (not only reproductive individuals) in total (140\%). We assume that the impact of supplemental feeding was very strong because, usually, a population decrease of up to $50 \%$ will occur after hibernation (GRULICH, 1960).

When planning the surface area of the site in the localities of restitution, it is necessary to consider the need for the mowed or grazed site to provide food and shelters, not only for the existing population but also for young individuals that expand into the surroundings of the colony after they leave their parental burrow. Recovery of the localities with habitats appropriate for the European ground squirrel and measures of repatriation were also implemented in Poland and the Czech Republic (MATĚJU et al., 2010), demonstrating the necessity for the provision of permanent management in the localities of ground squirrels. Permanently ensured suitable management (mowing or grazing) of the locality is also necessary. MATĚJÜ et al. (2010) further recommend keeping detailed documentation of the repatriation methods used and engage in regular monitoring of the newly founded populations. For restitution methods, airports are currently used as a resource for individuals. Due to suitable conditions, there is a sufficient number of European ground squirrels at airports. The high population density in the grasslands of airports is a result of the sufficient amount of food sources in such 
areas, the absence of less significant anthropic impacts, regular mowing, and the absence of chemical treatments of the grasslands, as well as sufficient free space for the dispersal of young ground squirrels before hibernation and regulation of the pressure from predators (AMBRos et al., 2004; BALÁž and AmBros, 2007). In the past, the ground squirrel was an undesired element at airports because of possible collisions between planes and raptors (CHAVKo et al., 2007; HorvátH et al., 2010, 2018). Thus, in the past, airports helpfully responded by transferring them to new localities, which was carried out alongside reinforcing the food base for, e.g., Aquila heliaca and Falco cherrug (BALÁž et al., 2008). Today, based on long-term monitoring, the ground squirrel is considered a desired element at airports and may even reduce the number of plane collisions with raptors. The reason for this reconsideration is because the ground squirrel is part of the food base of large raptors, mainly eagles, which have a great escape distance and low abundance. The localities missing the ground squirrel are inhabited by the common vole, which is the food base for smaller raptors with a smaller escape distance (Falco tinnunculus, Buteo buteo and Asio otus), whose abundance and density are, unlike the eagles-higher, which may ultimately lead to more frequent collisions (DANKo et al., 2002).

In open areas, the ground squirrel, where abundant, is considered a key species. When a colony is composed of hundreds of individuals, predators become attached to that colony as a source of food. Examples include species such as Mustela nivalis, M. putorius, and Felis silvestris, who are mostly hunted by Accipiter gentilis raptors (RužIĆ, 1978; HofFmann et al., 2004).

\section{Conclusions}

In the management of the European ground squirrel in the study localities, we noted the importance of supplemental feeding, which increased the likelihood of successful wintering and population growth. In the past, management focused mainly on mowing and grazing of the vegetation. However, these processes may be counter-productive, as they deprive plants of their seeds, which is a food source for ground squirrels.

The main problems for maintenance are the high level of division among the recovered localities, with a risk of inbreeding and unpredictable climatic events as floods. Successful management measures will require further attention and research focused mainly on the genetics of the studied populations.

It is also necessary to verify whether an increase in the population of the European ground squirrel is reflected by an increased number of birds of prey in the monitored areas.

\section{Acknowledgements}

The project results were achieved with the support of the LIFE 13 Project NAT/SK/001272, Energy in land-power lines and the conservation of priority bird species in NATURA 2000 sites. The authors express their thanks to Roman Slobodník from the Raptor Protection of Slovakia for their expert assistance in compiling this paper.

\section{References}

Ambros, M., 1999. Sysel pasienkový [European ground squirrel]. Metodické listy 14. Banská Bystrica: Slovenská agentúra životného prostredia - Centrum ochrany prírody a krajiny. 40 p.

Ambros, M., 2008a. Stav poznania rozšírenia sysl’a pasienkového (Spermophilus citellus L.) na Slovensku v rokoch 1996 až 2008 [Current knowledge on the distribution of the European ground squirrel (Spermophilus citellus L.) in Slovakia in 1996-2008]. Lynx (Praha) n. s., 39: 219-333.

Ambros, M., 2008b. Zachráni golf sysl'a na Slovensku? [Is golf going to rescue the ground squirrel in Slovakia?]. Chránené Územia Slovenska, 76: 16-18.

Ambros, M., Bobáková, L., Hapl, E., 2004. Poznámky k repatriácii sysl'a pasienkového na vybraných lokalitách Slovenska v rokoch 2000-2004 [Proposal of the gene flow network of the localities of the European ground squirrel (Spermophilus citellus) in Slovakia]. In KAUTMAN, J., StLouKal, E. (eds). Zbornik abstraktov z konferencie 10. Feriancove dni. Bratislava: Faunima, p. 32.

Ambros, M., Hapl, E., 2008. Výsledky transferu sysl'a pasienkového (Spermophilus citellus) z letiska v Bratislave na vybrané lokality na západnom Slovensku [Results of the European ground squirrel (Spermophilus citellus) transfer from the airport in Bratislava to the selected localities of Western Slovakia]. In Adamec, M., Urban, P., AdAmCoví, M. (eds). Výskum a ochrana cicavcov na Slovensku VIII. Zborník referátov z konferencie. Zvolen, 12. - 13. 10. 2007. Banská Bystrica: Štátna ochrana prírody SR, p. $72-85$.

Baláž I, Ambros, M., 2007. Porovnanie somatometrie populácií sysl'a pasienkového (Spermophilus citellus) na letisku MR Štefánika v Bratislave a na letisku v Košiciach [Somatometry comparison of European ground squirrel (Spermophilus citellus) populations at the MR Štefánik airport in Bratislava and at the Košice airport]. Reussia, 4: 247-256.

BalÁž, I., Jančová, A., Ambros, M., 2008. Reštitúcia sysl’a pasienkového (Spermophilus citellus) na Slovensku [Restitution of the European ground squirrel (Spermophilus citellus) in Slovakia]. Lynx (Praha) n. s., 39: 235-240.

BALÁž, I., ZALuBILOvÁ, L., 2005. Tradičné hospodárenie ako predpoklad zachovania sysl'a pasienkového....alebo zaujímavý osud druhu, v ktorého pozadí vždy stál človek [Traditional management as a precondition for the conservation of the European ground squirrel...or an interesting life story of the species which has a human always behind its back]. In BALÁž, I. (ed). Teória a prax krajinnoekologického plánovania. Zborník príspevkov z vedeckého seminára (Nitra 21. 5. 2004), konaný pri príležitosti životného jubilea prof. RNDr. Milana Ružičku, DrSc. Nitra: UKF v Nitre, p. 171-174. 
Belik, V., Galushin, V., Bogomolov, D., 2002. Results of the imperial eagle (Aquila heliaca) project in Russia during 1996 and 1997. Aquila, 107-108: 177-181.

Černecký, J., Galvánková, J., Považan, R., Saxa, A., SchefFER, J., SChefferová, A., LASÁK, R., JANÁK, M., 2014. Conservation status of habitats and species of Community interest in the period of 2007-2012 in the Slovak Republic. Banská Bystrica: State Nature Conservancy of the Slovak Republic. $1626 \mathrm{p}$.

Cнаvко, J., 2010. Trend and conservation of saker falcon (Falco cherrug) population in western Slovakia between 1976 and 2010. Slovak Raptor Journal, 4: 1-22. https:// doi.org/10.2478/v10262-012-0040-4

Chavko, J., Danko, S̆., Oвuch, J., Мiнóк, J., 2007. The food of the imperial eagle (Aquila heliaca) in Slovakia. Slovak Raptor Journal, 1: 1-18. https://doi.org/10.2478/v10262012-0001-y

Chavko, J., Deutschová, L., 2012. Population of saker falcon (Falco cherrug) in Western Slovakia between 1976 and 2010. Aquila, 119: 57-64.

Chavko, J., Slobodník, R., Deutschová, L., Lipták, J., Miно́к, J., Овuсн, J., Neмčек, V., 2014. The saker falcon (Falco cherrug) population, diet and nest boxes in Slovakia: LIFE-project report 2011-2014. Slovak Raptor Journal, 8: 73-86. https://doi.org/10.2478/srj-2014-0009

Colantoni, A., Egidi, G., Quaranta, G., D’Alessandro, R., Vinci, S., Turco, R., Salvati, L., 2020. Sustainable land management, wildfire risk and the role of grazing in Mediterranean urban-rural interfaces: a regional approach from Greece. Land, 9: 1-16.

Danila, I., 1989. Food of animal nature in the ground squirrel (Citellus citellus L.) in Romania. Analele Stiințifice ale Universității “Al. I. Cuza” din Iași. Ser. II, 35: 68-70.

Danko, Š., Darolová, A., KrišTín, A. (eds), 2002. Rozšírenie vtákov na Slovensku $=$ Birds distribution in Slovakia. Bratislava: Veda. 686 p.

Del Hoyo, J., Elliot, E., Sargatal, J., 1995. Handbook of the birds of the world. Vol. 2. Falconiformes to Galliformes. Barcelona: Lynx Edicions. 638 p.

Grulich, I., 1955. Sysel obecný v podmínkách intensivního zemědělství [European ground squirrel in conditions of intensive agriculture]. Živa, 3: 149-150.

Grulich, I., 1960. Sysel obecný (Citellus citellus L.) v ČSR [European ground squirrel Citellus citellus L. in Czechoslovakia]. Práce Brněnské Základny ČSAV, 32: 473-563.

Grulich, I., 1980. Savci a zemni stavby v kulturocenózách [Mammals and earth structures in agrocoenoses]. Quaestiones Geobiologicae, 24-25. Bratislava: Veda. $159 \mathrm{p}$.

Hapl, E., 2001. Repatriácia sysl'a pasienkového [Repatriation of the European ground squirrel]. In Uhrin, M. (ed). Ročenka 1999-2000: Národný park Muránska planina. Revúca: Správa Národného parku Muránska planina, p. 27-29.

Hapl, E., Ambros, M., OleKšÁK, M., Adamec, M., 2006. Reštitúcia sysl'a pasienkového (Spermophilus citellus) $v$ podmienkach Slovenska. Metodická príručka [Restitution of the European ground squirrel (Spermophilus citellus) in the Slovak conditions. Methodological manual]. Banská Bystrica: Štátna ochrana prírody SR. 24 p.

Hapl, E., Löbová, D., Deutschová, L., Chreneková, M.,
2018. Kto sysl’ovi jamu kope, zbytočne sa trápi [Who digs a hole for a ground squirrel wastes his time]. In KubovČík, V., StašIOv, S. (eds). Zborník abstraktov z vedeckého kongresu "Zoológia 2018". 22. - 24. november 2018, Zvolen. Zvolen: Technická univerzita vo Zvolene, 2018, p. 43.

Haraszthy, L., Bagyura, J., Szitta, T., Petrovils, Z., VisZLÓ, L., 1996. Biology, status and conservation of the imperial eagle Aquila heliaca in Hungary. In Meyburg, B.U., Chancellor, R.D. (eds). Eagle studies. Berlin, London, Paris: World Working Group on Birds of Prey, p. $425-427$.

Hartel, T., Dorresteijn, I., Klein, C., Máthé, O., Moga, C.I., Öllerer, K., Roellig, M., Wehrden H. von, FisCHER, J., 2013. Wood-pastures in a traditional rural region of Eastern Europe: characteristics, management and status. Biological Conservation, 166: 267-275. https:// doi.org/10.1016/j.biocon.2013.06.020

Hoffmann, I.E., Muck, E., Millesi, E., 2004. Why males incur a greater predation risk than females in juvenile European sousliks (Spermophilus citellus). Lutra, 47: 85-94.

Horváth, M., Solti, B., Fatér, I., Juhász, T., Haraszthy, L., Szitta, T., BallóK, Z., PÁsztory-Kovács, S., 2018. Temporal changes in the diet composition of the Eastern imperial eagle (Aquila heliaca) in Hungary. Ornis Hungarica, 26:1-26. https://doi.org/10.1515/orhu-2018-0001

Horvíth, M., SzitTa, T., FirmánszKy, G., Solti, B., Kovács, A., Moskát, C., 2010. Spatial variation in prey composition and its possible effect on reproductive success in an expanding Eastern imperial eagle (Aquila heliaca) population. Acta Zoologica Academiae Scientiarum Hungaricae, 56: 187-200.

Hulové, Š., 2001. Rozšírení a biotop sysla obecného (Spermophilus citellus) v současných podmínkách na území Čech [Distribution and habitat of the European ground squirrel (Spermophilus citellus) in present conditions in Bohemia]. Bachelor thesis. Biologická fakulta Jihočeské univerzity, České Budějovice. 29 p. Unpublished.

Karaska, D., Trnka, A., Krištín, A., Ridzoň, J., 2015. Chránené vtáčie územia Slovenska [Special protection areas in Slovakia]. Banská Bystrica: Štátna ochrana prírody Slovenskej republiky. 383 p.

Karyakin, I.V., Nikolenko, E.N., Levin, A.S., Kovalenko, A.V., 2011. Eastern imperial eagle in Russia and Kazakhstan: population status and trends. Acta Zoologica Bulgarica, 3: 95-104.

Kenyeres, Z., Bauer, N., Nagy, L., Szabó, S., 2018. Enhancement of a declining European ground squirrel (Spermophilus citellus) population with habitat restoration. Journal for Nature Conservation, 45: 98-106. https://doi. org/10.1016/j.jnc.2018.08.006

KLINDA, J., 2000. Terminologický slovník environmentalistiky [Terminological dictionary of environmental science]. 1st edition. Bratislava: Ministerstvo životného prostredia SR. $764 \mathrm{p}$.

KomáreK, J., 1950. Česká zvířena [Czech animals]. 2nd edition. Melantrich, Praha. 345 p.

Kosmas, C., Detsis, V., Karamesouti, M., Kounalaki, K., Vassiliou, P., Salvati, L., 2015. Exploring long-term 
impact of grazing management on land degradation in the socio-ecological system of Asteroussia Mountains, Greece. Land, 4: 541-559.

Matěsů, J., Říčanová, Š., Ambros, M., Kala, B., Hapl, E., MATĚJU, K., 2010. Reintroductions of the European ground squirrel (Spermophilus citellus) in Central Europe (Rodentia: Sciuridae). Lynx (Praha), n. s., 41: 175-191.

Millesi, E., Hoffmann, I.E., 2008. Body mass and timing of the active season in European ground squirrels (Spermophilus citellus) at high and low population density. Lynx (Praha), n. s., 39: 305-315.

Овuch, J., Chavко, J., 1997. Potrava sokola rároha (Falco cherrug) na juhozápadnom Slovensku [The saker falcon diet (Falco cherrug) in south-western Slovakia]. Buteo, 9: $77-84$.

RuŽıć, A., 1978. Der oder das Europäische ziesel (Citellus citellus). In Niethammer, J., Krapp, F. (eds). Handbuch der Säugetiere Europas. Band 1, Rodentia I (Sciuridae, Castoridae, Gliridae, Muridae). Wiesbaden: Akademische Verlagsgesellschaft, p. 122-144.

Seaman, D.E., Griffith, B., Powell, R.A., 1998. KERNELHR: a program for estimating animal home ranges. Wildlife Society Bulletin, 26: 95-100.

Spitzenberger, F., Bauer, K., 2001. Ziesel Spermophilus citellus (Linnaeus, 1766). In Die Säugetierfauna
Österreichs. Grüne Reihe des Bundesministeriums für Land- und Forstwirtschaft Umwelt und Wasserwirtschaft, Bd. 13. Graz: Bundesministerium für Land- und Forstwirtschaft, Umwelt und Wasserwirtschaft, p. 356-365.

TuHÁrska, K., BALÁž, I., 2006. Záchrana sysl’a pasienkového na západnom Slovensku [Preservation of the European ground squirrel in Western Slovakia]. Enviromagazin, 11 (3): 22.

Urban, P., Uhrin, M., 2014. Draft Carpathian Red list of threatened mammals (Mammalia). In KADLEČíK, J. (ed.). Carpathian Red list of forest habitats and species, Carpathian list of invasive alien species. Banská Bystrica: State Nature Conservancy of the Slovak Republic, p. 221-227.

ŽıaK, D., Urban, P., 2001. Červený (ekosozologický) zoznam cicavcov (Mammalia) Slovenska In BALÁž, D., MARHOLD. K., URBAN, P. (eds). Červený zoznam rastlín a živočichov Slovenska [Red list of plant and animal species of Slovakia]. Ochrana prírody, 20, Suplement. Banská Bystrica: Štátna ochrana prírody Slovenskej republiky, p. 154-156.

Submitted February 9, 2021 Accepted June 8, 2021 